\title{
MAQUIAVEL E O GOVERNO DAS LEIS: A RELAÇÃO ENTRE AS LEIS, AS INSTITUIÇÕES POLÍTICAS E 0 CONFLITO
}

\author{
Machiavelli and the Government of Laws: The relation between Law, Political \\ Institutions and Conflict \\ Ricardo Manoel Morais \\ Universidade de São Paulo \\ ricardo_mom@hotmail.com
}

\begin{abstract}
Resumo:
O objetivo é analisar as contribuições maquiavelianas para pensar o surgimento das boas leis e instituições políticas a partir do conflito, apresentando algumas reflexões sobre a relação entre a teoria política do Florentino e a teoria médica antiga. Para Maquiavel, uma comunidade política bem ordenada é aquela na qual boas leis (produzidas com ampla participação) governam. Com isso, será observado que Maquiavel foi um defensor de um governo que se regesse por leis estabelecidas por um processo participativo e conflitivo. Primeiramente será examinado que o conflito, para Maquiavel, é uma marca ontológica da política, ou seja, não pode ser extirpado, razão pela qual as cidades devem ordená-los para que eles não gerem efeitos nocivos. Após, será observado que numa cidade bem ordenada, os conflitos criam um campo propício para boas leis e ordenações se consolidarem.
\end{abstract}

\section{Palavras-chave:}

conflitos, leis, ordenações, comunidade política, humores

\begin{abstract}
:
The purpose is to analyze some machiavellian contributions to think about the emergence of the good laws and political institutions from the conflict, presenting some reflections on the relation between the Florentine's political theory and the ancient medical theory. For Machiavelli, a wellordered political community is one in which good laws (produced with broad participation) govern. With this, it will be examined that Machiavelli was an advocate of a government ruled by laws established after a participatory and conflicting process. It will first be examined that the conflict, for Machiavelli, is an ontological mark of politics, that is, it can not be extirpated, which is why cities should order them, so that they do not generate destructive effects. Then it will be exposed that in a wellordered city, conflicts create a conducive environment for good laws and ordinations to be consolidated.
\end{abstract}




\section{Keywords:}

conflicts, laws, ordinations, political community, humors

Recibido: $12 / 06 / 2020$

Aceptado: 14/12/2020

\section{INTRODUÇÃO}

Este texto tem por objetivo compreender, na obra de Maquiavel, a relação entre a emergência das boas leis e instituições políticas e o conflito como motor da vida política. Conforme será examinado, para o pensador florentino, o conflito entre dois humores (os dos grandes, que é opressor, e o da plebe, que quer evitar a opressão) é uma marca ontológica da realidade de toda e qualquer comunidade política. Entretanto, o conflito pode tanto gerar efeitos positivos, ocasionando um campo político propício para o exercício da virtù e da liberdade, quanto efeitos negativos, o que leva a um enfraquecimento da cidade e a uma oscilação entre um regime licencioso e a tirania. Com efeito, a análise empreendida neste texto tem como escopo expor a profunda relação existente entre a teoria política de Maquiavel e a teoria médica antiga, sendo esta mais do que uma simples metáfora, mas a chave de compreensão da dinâmica do corpo social, suas convulsões, conflitos, saúde, equilíbrio, doenças.

Devido ao escopo deste artigo, será atribuída maior atenção a uma bibliografia que vem se consolidando a partir da influência lefortiana na interpretação do republicanismo maquiaveliana, presente em Ames, Bignotto, Adverse. A obra de McCormick assume considerável relevância pois, embora não seja lefortiana, confere destaque à problemática do conflito na institucionalidade, bem como ao potencial desinstitucionalizante do político. Com isso, não se ignora a proeminência das interpretações canônicas do Renascentismo, mas para sustentar uma das principais hipóteses defendidas neste texto - a do caráter ontológico do político para Maquiavel -, optou-se por uma investigação mais fluida analiticamente.

Maquiavel, embora atribua ao conflito um papel central em suas análises, não promove um elogio irrestrito desta categoria. Diferentemente disso, ele apenas assume que o conflito é uma realidade que não pode ser extirpada da vida em comunidade, devendo as instituições e os atores políticos institucionalizá-lo, dando a ele uma vazão institucional a fim de que ele não corroa a polis. Neste sentido, será evidenciado que Maquiavel não apenas se contrapõe à tradição que o precede ao colocar o conflito como marca ontológica, como é extremamente original ao defender que os conflitos devam fazer parte da ordem institucional das cidades, caso contrário abre-se um campo de conflitos não institucionalizado, mas faccioso, o que leva a um enfraquecimento da cidade e, como mencionado, cria um ciclo vicioso que faz com que o regime político oscile entre tirania e licença. 
Neste sentido, primeiramente serão examinadas as potencialidades (positivas ou negativas) do conflito político no pensamento de Maquiavel. Em seguida, serão analisadas as divisões ou humores que, por serem antagônicos, se enfrentam, enfrentamento este do qual podem surgir boas leis e instituições (ocasionando o governo das leis) ou disputas facciosas que levam ao enfraquecimento da cidade e ao reforço da tirania. A necessidade de se compreender a teoria dos humores em Maquiavel decorre do fato de que seu pensamento foi influenciado pela teoria médica antiga, sendo as analogias fisiológicas instrumentos de suma importância para se compreender a questão da saúde (compreendida como liberdade e governo das boas leis) ou da doença (compreendida como disputas facciosas que enfraquecem o corpo político) da cidade. Assim, será evidenciada a questão do governo das leis propriamente e a relação disso com a boa tradução institucional dos conflitos.

\section{AS POTENCIALIDADES DO CONFLITO POLÍTICO}

Maquiavel, por mais que não examine os eventos históricos visando a uma objetividade histórica, parte de exemplos paradigmáticos e, com isso, suscita questões políticas importantes sobre o espaço da cidade. Ao analisar os conflitos que podem levar uma comunidade política à perfeição política, o florentino remete este problema a questões mais profundas, que dizem respeito à essência das comunidades políticas. Para Gaille Nikodimov (2004: 13), existiram, em todas as comunidades políticas, diferenciações fundamentais entre castas sociopolíticas. A história, tanto antiga quanto a moderna, evidencia a irrupção deste universo das cidades maquiavelianas, retratando o modo como o conflito desempenha o papel de motor da vida coletiva a partir de cisões diferenciadoras entre poder e oposição, maioria e minoria, explorador e explorado.

O conflito emerge de uma oposição fundamental entre os dois humores, o dos grandes e o da plebe, tema tratado por Maquiavel em suas principais obras. Se em $O$ príncipe esta temática é tratada brevemente a partir de reflexões sobre o principado civil no Capítulo IX, nas demais (Discursos e História) Maquiavel coloca a questão dos enfrentamentos entre os humores no centro de suas análises, embora aborde o tema em contextos históricos diferentes. Nos Discursos são analisados eventos da Roma antiga e na História são problematizados acontecimentos de Florença. Além disso, nos Discursos Maquiavel desenvolve uma argumentação que ressalta as potencialidades positivas dos conflitos ao passo que na História ele retrata seu potencial nocivo à comunidade política.

Devido a isso, surgiram interpretações que sustentam haver uma reorientação teórica sobre a questão do conflito dos Discursos para a História. Os Discursos seriam elogiosos para com os tumultos promovidos pela plebe e à forma como o humor popular foi decisivo para a instituição e a manutenção da liberdade em Roma, tendo tido um papel determinante no alcance da perfeita ordenação desta república. Já na História Maquiavel teria adotado um tom recriminador em relação ao povo florentino por ter protestado contra a opressão da elite por meio de uma insurreição, assumindo um tom mais elogioso em relação ao humor dos grandi. Por estas razões, alguns estudiosos irão posicionar as reflexões da História como sendo uma tentativa de 
Maquiavel de agradar seus leitores mais imediatos, hipótese defendida por McCormick (2013). Isso porque a referida obra foi escrita mediante encomenda formal dos Medici.

Todavia, tal interpretação é questionável na medida em que o próprio Maquiavel não afirma que está deixando de lado suas posições anteriores. Assim, realizar este salto interpretativo é arriscado. O que se pode depreender de uma análise depurada das obras é que as supostas rupturas no exame dos conflitos não decorreriam de um deslocamento conceitual ou de um "objetivo oculto" de aprazer seus leitores imediatos, mas do fato de que nos Discursos Maquiavel analisa os efeitos positivos dos conflitos, ao passo que na História ele analisa os seus efeitos nocivos. Como mencionado, Maquiavel não afirma que o conflito é um bem em si mesmo, mas que, sendo uma marca ontológica da política, pode gerar efeitos institucionais positivos ou negativos. Em Roma os conflitos entre povo e senado geraram efeitos positivos, pois foram instituídos os tribunos e meios de os humores desafogarem os ânimos institucionalmente, como a acusação pública. Neste sentido, quando os conflitos geram efeitos positivos, as instituições ou os atores políticos, ao final de um enfrentamento, são capazes de traduzi-los em boas leis e ordenações. Por outro lado, como podem também gerar efeitos negativos, quando isso ocorre, a cidade é enfraquecida e, com isso, a diferenciação entre os humores, a liberdade e a ordem republicana são ameaçadas.

Tanto não há que se falar numa ruptura conceitual em relação ao tema dos conflitos que o próprio Maquiavel, nos Discursos compara a diferença dos efeitos dos conflitos em Roma e em Florença. Neste sentido é a tese sustentada por Gaille Nikodimov (2004), segundo a qual o tema dos conflitos em Maquiavel não sofre mutações no decorrer da obra, mas é, sobretudo, tratado com "notável coerência" em todo seu trabalho. As supostas diferenças nas análises maquiavelianas sobre o tema dos conflitos se dariam não por uma guinada em seu pensamento, mas por uma diferença nos efeitos em potencial que os conflitos civis podem gerar. Logo, sendo, para Maquiavel, a política definida pelo conflito, parece acertado adotar a tese de que sua obra não é marcada por uma ruptura conceitual, pois os conflitos podem gerar efeitos distintos no âmbito de comunidades distintas.

Ainda conforme Gaille Nikodimov (2004: 29), a própria distinção dos conflitos a partir dos seus efeitos, que podem ser positivos ou negativos, está presente na convicção de que a manutenção da liberdade está diretamente conectada à desunião entre povo e nobreza. Isso porque a liberdade não surge de qualquer conflito, havendo aqueles que levam as cidades à extrema violência e à destruição. Assim, os conflitos podem ocasionar os seguintes efeitos: 1) os humores podem encontrar uma oposição equilibrada, fazendo com que a liberdade se consolide nas instituições, como se deu em Roma; 2) os conflitos entre os humores, mesmo que ocorram de forma perene, não encontram vazão institucional, gerando efeitos negativos para a cidade, fazendo com que ela oscile entre licença e tirania (Ames, 2009: 186). Este é o ponto diferenciador dos desdobramentos dos conflitos em Roma e em Florença. Roma, mesmo não tendo sido bem ordenada de início, retificou seu caminho. Neste sentido, foram sentidos em Roma parte dos efeitos negativos dos conflitos, mas, por força de acidentes, os romanos consolidaram boas instituições e os conflitos puderam ocasionar bons efeitos. 
Florença, por outro lado, teve sua história marcada pelo terceiro efeito em potencial dos conflitos.

Roma nasceu como um principado e, com o passar do tempo, se corrompeu. Tão logo os Tarquínios foram depostos, pairou um aspecto de união entre povo e senado, "[...] e parecia que os nobres haviam renunciado à soberba, que tinham disposições mais populares e podiam ser suportados por todos, mesmo os de ínfima condição". Enquanto os Tarquínios estavam vivos, a aparente união persistiu. Os nobres receavam que a plebe, se maltratada, se reaproximasse dos reis depostos. Todavia, quando estes morreram, o senado perdeu o medo do povo, passando a desrespeitá-lo, o que fez com que a plebe provocasse uma série de tumultos e, após "[...] muitas confusões, tumultos e perigos de perturbações, surgidos entre a plebe e a nobreza, chegou-se à criação dos tribunos, para a segurança da plebe" (Maquiavel, 2007: 20-21). Assim, os tumultos e o medo dos nobres fizeram com que Roma chegasse a uma boa ordenação, o que se deveu à contingência e a virtù da plebe. Se o povo não tivesse reagido no momento correto ou não tivesse feito as exigências de forma ponderada, Roma poderia ter se corrompido antes de ser uma república.

Importante frisar que o conflito protagonizado pelo povo, para que tenha um bom desfecho, deve gerar bons efeitos institucionais. Não é porque Maquiavel coloca o conflito como um elemento primordial da vida institucional de uma cidade que disso se possa inferir que ele promove um elogio irrestrito do conflito cívico (Gaille Nikodimov, 2004; Ames, 2014). O próprio Maquiavel, nos Discursos compara a diferença dos efeitos dos conflitos em Roma e em Florença ao discorrer sobre a importância da ordenação das acusações públicas1 e do tribunato, sendo esta uma instituição de mediação entre povo e senado. Os escritos de Lívio acerca da criação dos tribunato (instituição que efetivava a participação plebeia e viabilizava o controle sobre os grandi) demonstram claramente os fatos narrados por Maquiavel sobre os eventos que levaram Roma à perfeição institucional (McCormick, 2013: 259-260).

Roma, para que chegasse à perfeita ordenação, passou por períodos nos quais a plebe teve de se valer de vias extraordinárias, promovendo tumultos e desordens. Embora estes conflitos tenham tido um desfecho positivo, que foi a instituição dos tribunos e a ampliação de participação popular, o recurso ao extraordinário pode trazer efeitos nocivos à cidade (Morais, 2014). Em toda cidade onde não é possível que os humores encontrem meios ordinários para desafogar os ânimos, há o risco de os conflitos acarretarem males à cidade. Logo, as vias extraordinárias em geral podem gerar efeitos positivos em cidades que, não tendo se ordenado de forma a desafogar

\footnotetext{
1 "[...] como se disse, era bem-ordenada em Roma; e foi sempre mal ordenada na nossa cidade de Florença. E, assim como em Roma essa ordenação fez muito bem, em Florença essa desordem fez muito mal. E quem lê as histórias desta cidade verá quantas calúnias foram lançadas em todos os tempos contra seus cidadãos que trabalharam nas coisas importantes da cidade. De um diziam que havia roubado o dinheiro público; de outro, que não vencera uma empresa por ter sido corrompido; e que aqueloutro, por ambição, cometera este ou aquele inconveniente. Motivo por que de todos os lados surgia o ódio: deste se chegava à divisão, e da divisão às facções; das facções à ruína. Porque, se em Florença tivesse havido uma ordenação que possibilitasse a acusação dos cidadãos e punisse os caluniadores, não teriam ocorrido os infinitos tumultos que ocorreram" (Maquiavel, 2007: 39).
} 
os ânimos dos humores de início, podem vir a alcançar a perfeita ordenação por força da contingência. Assim, se Roma teve sua história marcada por dissenções e um recurso ao extraordinário com um bom desfecho, o mesmo não se deu em Florença.

Maquiavel, no primeiro capítulo do Livro III da História, sintetiza novamente de forma bastante clara as diferenças entre os efeitos dos conflitos em Florença e em Roma, elucidando o motivo pelo qual o conflito em Florença era reprovável.

As graves inimizades que há entre os homens do povo e os nobres, causadas pela vontade que esses têm de comandar e aqueles de não obedecer, são a razão de todos os males das cidades; porque dessa diversidade de humores alimentam-se todas as outras coisas que perturbam as repúblicas. Foi o que manteve Roma desunida; é também - se for lícito comparar coisas pequenas e coisas grandes - o que manteve Florença dividida; se bem que os efeitos gerados em cada uma das cidades foram diferentes: porque as inimizades havidas em Roma, em princípio, entre o povo e os nobres eram definidas por disputas, enquanto as de Florença o eram por combates; as de Roma terminavam com leis, enquanto as de Florença terminavam com o exílio e com a morte de muitos cidadãos; as de Roma sempre aumentavam a virtù militar, enquanto as de Florença a extinguiam totalmente; em Roma, a igualdade entre os cidadãos levou a grandíssima desigualdade, enquanto em Florença, de desigualdade, chegou-se a uma admirável igualdade. Tal diversidade de efeitos só pode ser causada pelos diferentes fins que os dois povos tinham em mira: porque o povo de Roma desejava gozar as supremas honras ao lado dos nobres, enquanto o de Florença combatia para ficar sozinho no governo, sem a participação dos nobres. E, como o desejo do povo romano era mais razoável, as ofensas aos nobres acabavam por ser mais suportáveis, de tal modo que aquela nobreza cedia facilmente e sem recorrer às armas; assim, depois de algumas desavenças, concordavam em criar uma lei que satisfizesse ao povo e aos nobres em seus cargos. Por outro lado, o desejo do povo florentino era injurioso e injusto, de tal modo que a nobreza preparava sua defesa com maiores forças, e, por isso, chegava-se ao derramamento de sangue e ao exílio dos cidadãos, e as leis depois criadas não miravam à utilidade comum, mas eram ordenadas todas a favor do vencedor (Maquiavel, 2007: 157-158).

Também no capítulo 34 do Livro II da História Maquiavel expõe que embora muitas repúblicas tenham tido divisões claras, grande parte delas consolidou só uma divisão (povo e grandes), que ora ampliou a cidade ora a arruinou. Em Florença, todavia, originaram-se inúmeras divisões (não apenas a clássica divisão romana entre plebe e nobreza) que progressivamente a arruinavam: primeiramente, os primeiros nobres se dividiram entre si; em seguida, houve uma divisão entre os nobres e o povo; por fim, surge uma divisão entre povo e plebe. Uma destas partes, tendo vencido um confronto e se sobreposto (de modo a anulá-la), se dividia. Ainda, sempre que um confronto 
ocorria entre as referidas divisões, ao final dele haviam inúmeras mortes, exílios e destruições de famílias.

Os conflitos em Florença são complexos pois as oposições fundamentais entre os humores se tornaram fluídas e artificiais, não naturais. Os grupos que passam a se confrontar não o fazem quando se trata de discórdias inevitáveis, porquanto as divisões se dão dentro de um mesmo humor e são, por conseguinte, artificiais. Isso evidencia o motivo pela qual Maquiavel relança sua análise dos conflitos criticando seus efeitos em Florença. "[...] em Roma, era o fundamento da liberdade e grandeza da república e, portanto, positivo; em Florença, nutre a contínua crise, 'origem de tantas mortes, tantos exílios, tantas destruições de famílias' e, portanto, negativo" (Ames, 2014: 268).

Em Florença, o desejo do povo foi além da luta por não dominação, tendo ele desenvolvido um desejo de dominação que só poderia ser desenvolvido em detrimento dos grandes. Em outras palavras, o modo pelo qual o humor da plebe desejou passou a não mais ser diferenciado em relação ao dos grandes. Assim, se em Roma o desejo popular era racional, em Florença ele era injurioso e injusto, tendo por efeito o constante descontentamento e a exclusão das novas divisões artificiais que surgiam. A oposição entre os contrários não se traduzia em liberdade, mas numa concorrência "extraordinária" das facções pela conquista do poder político, que levou a um enfrentamento violento e nocivo para a polis.

A estrutura constitucional florentina foi marcada por divisões nocivas. As principais famílias nobres florentinas se alinharam aos partidos guelfo ou gibelino, alianças em relação às quais se somaram elementos populares, fazendo com que quase toda a cidade fosse mergulhada em conflitos de caráter privado e extraordinário. Esta divisão determinou a criação de ordenações militares e civis na cidade, sempre de modo a estancar o confronto entre os grupos e, uma vez que os conflitos não devem ser abafados, esta forma de lidar com a realidade política degradava cada vez mais a polis florentina. "A disputa entre eles deixa patente que é unicamente a vontade de poder e domínio que os nutre, razão pela qual Maquiavel conclui que 'é impossível que coexistam"' (Ames, 2014, p.269). Tanto que as saídas institucionais propiciadas para a resolução destes conflitos foram impotentes para regular a vontade de poder dos grupos, tendo tido seus efeitos eram passageiros e constantes rupturas institucionais. Mais uma vez, a possível causa da insuficiência destas ordenações pode ter se devido ao fato de que em Roma os humores eram claramente diferenciados ao passo que em Florença eram mutáveis, sem uma clara determinação para sua regulamentação e institucionalização.

Esta questão se torna mais clara a partir da análise maquiaveliana do tumulto dos Ciompi. Segundo Ames (2014: 274), esta revolta, promovida pelos cardadores de lã florentinos, pode ser analisada como a perversão da luta política em uma luta econômica, a "[...] transformação da discórdia civil em guerra civil; recurso aos meios privados em substituição aos públicos; emergência de líderes individuais de ambos os lados em confronto e a consequente emergência de um poder único - César em Roma, Cosimo em Florença". O motivo que acarretou a revolta foi o ódio do povo aos cidadãos ricos por parecer que eles não eram pagos com justiça pelo seu trabalho. Maquiavel contrapõe o discurso do gonfaloneiro Luigi Guicciardini ao de um chefe 
dos revoltos. O gonfaloneiro exorta a moderação, "[...] argumentando que todas as reivindicações razoáveis do popolo minuto já foram satisfeitas, o do ciompo é um apelo a um confronto violento argumentando que o principal - a riqueza e sua forma de produção - ficou intacto" (Ames, 2014: 274). O gonfaloneiro destaca os ganhos políticos que o popolo minuto alcançou, dizendo que tudo o que poderia ser concedido já foi feito. Com relação às questões econômicas, ele tenta mostrar a irrazoabilidade da pretensão dos revoltos quanto à repartição dos bens de modo a promover a igualdade econômica.

O discurso do gonfaloneiro procura convencer seus interlocutores de que a produção das riquezas das quais a cidade vive requer uma habilidade (industria) que somente os grandes detêm. Pretender colocar em discussão as "relações de produção" implicaria comprometer a própria sobrevivência e, portanto, que reivindicações no sentido de uma igualdade econômica ou participação na roba redundariam, no final das contas, em prejuízo de todos. A roba, como podemos notar, assume um sentido mais vasto do que somente riqueza: refere-se à própria "ordem econômica", isto é, à forma como a riqueza é produzida e repartida. Desta maneira, as palavras de Guicciardini explicitam o contraste entre um conflito em que se combate por onori e aquele em que se luta pela roba [Se o primeiro pode levar a um acordo pacífico, a segundo sempre resulta em desordens, violência e instabilidades] (Ames, 2014: 275).

Já o discurso do líder dos ciompi se inicia com a proposição de um confronto violento com a parte adversária que está no poder. Quanto maior for a violência empregada, maior será a chance de escapar da vingança, pois não haveria qualquer possibilidade de composição. Para ele, mesmo reconhecendo que utilizar armas, queimar e roubar as casas dos cidadãos é um mal, a única forma de os revoltos serem perdoados pelos erros anteriores é duplicar os males cometidos. Ele afirma que os que vencem o fazem empregando os meios que forem necessários, jamais tendo vergonha disso. Ainda, todos os que conseguem riquezas o fazem por meio de fraudes e força, ao passo que aqueles que evitam tais métodos se afundam em servidão e pobreza. Assim, ele conclui que é preciso empregar a força, aproveitando que os cidadãos ainda estão desunidos, a senhoria incerta e os magistrados assombrados.

Para Ames (2014: 276), Maquiavel se admira da iniciativa dos ciompi em enfrentar os senhores ao invés de depender da boa vontade deles. Conforme o florentino expressa em O príncipe, em circunstâncias em que a vida e a liberdade estão em jogo, há a necessidade de recusar meias-medidas e de ter coragem para ser "inteiramente mau", mostrando-se a consciência moral uma mordaça destinada a desencorajar a revolta ou inibir a força da ação. Todavia, ainda que ele tenha se admirado da postura dos revoltosos, não assume uma posição favorável em relação às reivindicações deles. O ciompo defende que "A nobreza não tem, em si mesma, qualquer valor; a distinção da qual estes se revestem é puramente exterior, aparente, sustentada na riqueza [...]" (Ames, 2014: 277). O que conferiria poder seriam unicamente as riquezas, não a honra e glória. Só a força e a fraude contariam para alcançar a riqueza e, por conseguinte, o 
poder. Se a distinção dos nobres não brota de uma característica especial, mas da riqueza e da fraude, fraudar e enriquecer seria o modo de superar a servidão. A luta dos ciompi mereceria louvor pois não há, no plano da natureza humana, nenhuma marca que faça de uns nobres e de outros plebeus a ponto de se justificar a dominação "natural" de uns sobre outros. Todavia, Maquiavel não promove um elogio irrestrito aos tumultos e desordens pois a aspiração de ser livre não deve se degenerar em licença, o que leva ao reforço da tirania ou da licença, que foi o que ocorreu em Florença (Ames, 2014: 277-278).

Tendo em vista que os revoltosos objetivavam o monopólio do poder em detrimento dos demais, isso evidencia que eles não eram movidos pelo bem comum. Mesmo que os humores tendam ao excesso, o conflito só gera efeitos positivos se os humores se confrontem mantendo o modo de desejar diferenciado. Quando os ciompi empregam força e fraude ao invés de tentar fazer valer uma lei que coíba tais práticas, o modo como eles desejam passa a ser igual os dos grandes. Com isso, os conflitos geram efeitos nocivos. Ainda, depois de encerrado este enfrentamento, não foram criadas instituições capazes de refrear a desmesura dos humores, fazendo com que Florença se degenerasse em novas divisões e enfrentamentos extraordinários.

Neste sentido, o caráter extremo do conflito florentino, que não tem por objetivo sua inserção institucional do povo, simplesmente reforça o emprego das vias extraordinárias, criando uma guerra civil entre facções privadas. Pode-se dizer que "[...] por ver no exercício do poder político unicamente uma oportunidade para ampliar o ganho e a acumulação, o tumulto assume unicamente um significado negativo [...]. Quando o conflito assume esta feição, o mais provável é o surgimento de líderes individuais" (Ames, 2014: 79).

Assim, na História Maquiavel enuncia que existem cidades que apenas adotam o nome de república, quando na verdade mudam sua forma de governo a todo instante alternando não entre liberdade e servidão, mas entre servidão e licença. Se a liberdade é exaltada pelas plebes, a servidão o é pelos grandes. Nestas cidades, nenhum dos humores deseja se submeter aos homens e às leis, e é justamente esta a causa da oscilação. Levando em conta que estas alternâncias enfraquecem a cidade perante seus inimigos, Maquiavel conclui que Florença, ao variar entre uma forma de governo tirânica e outra licenciosa, dificilmente pode alcançar alguma estabilidade e jamais a grandiosidade. Neste tipo de "república" o que se multiplicam são as divisões. "Às 'naturais' discórdias somam-se as 'artificiais' disputas pelo controle do Estado como instrumento de ganho e acumulação" (Ames, 2014: 279).

\section{OS HUMORES EM CONFLITO}

Até aqui se falou de humores, desígnios, desejos ou impulsos sociais fundamentais e antagônicos, um dos grandi e outro da plebe, que se enfrentam na comunidade política. Para Maquiavel, em toda cidade existem estes dois humores que se manifestam com os seguintes impulsos: "o povo não quer ser comandado nem oprimido pelos grandes, enquanto os grandes desejam comandar e oprimir o povo [...]" (Maquiavel, 2007: 43). Estes humores antagônicos constituem a dinâmica fundamental de toda civilização (civiltà). A natureza do desejo dos grandi (nobres; aristocratas; patrícios; grandes) é positiva e determinada, pois quer oprimir e aumentar 
sua dominação, ao passo que o do povo é indeterminado e negativo, operando de modo a não ser oprimido (Adverse, 2007). Para Gaille Nikodimov (2004: 33), o conceito de humor (umore ou omore) é uma noção chave para compreender as condições de possibilidade para o surgimento e a manutenção de um regime livre2. Embora ausentes nos escritos de chancelaria, elas aparecem de forma recorrente em OPríncipe, nos Discursos e na História. As principais referências a esta temática estão: no capítulo IX e no XIX de O príncipe; nos oito primeiros capítulos do Livro I dos Discursos; nos Livros II e III da História.

Nos Discursos a questão dos humores antagônicos é o determinante institucional, uma vez que as leis favoráveis à ampliação institucional e à manutenção da liberdade na república romana advieram da desunião conflituosa entre os grandes e o povo. Todas as questões apresentadas nesta parte da obra parecem estar relacionadas com a questão da distribuição das magistraturas e das formas de os humores desafogarem os ânimos, pois estes são fatores decisivos para a manutenção da liberdade cívica. Tratase de assegurar que nenhum humor se sobreponha ao outro, sobretudo o dos grandes, que deve ser refreado para que não domine ou anule o outro. A forma como a descrição dos humores aparece nesta obra fornece uma pista no sentido de que os estratos sociais descritos não correspondem, necessariamente, a divisões sócioeconômicas (Adverse, 2007). Evidente que esta dimensão não pode ser descartada, mas o que subjaz a cisão social parece ser uma identidade de interesses entre segmentos no sentido de um valor coletivo (opressão ou não opressão), sendo esta a origem da agregação entre indivíduos e do antagonismo entre coletividades. $\mathrm{Na}$ medida em que os desejos humanos tendem à imoderação, eles acabam por se chocar e, ao se projetarem na vida política, levam a divisões naturais. Caso a essas divisões sejam somadas divisões artificiais, há um enfraquecimento da humor. Caso um humor imponha ao outro o seu modo de desejar, acaba-se a heterogeneidade, levando a polis à corrupção e à degeneração das instituições políticas. É justamente quando o elemento diferenciador entre as classes passa a se restringir ao elemento econômico que há a corrupção do humor do povo, como Maquiavel demonstra em sua análise da revolta dos Ciompi.

Também as reflexões trazidas na História relacionam o confronto entre os humores às questões institucionais, mais especificamente, a reivindicações políticas que jamais podem ser satisfeitas inteiramente no campo institucional. Inicialmente, parece haver elementos teóricos que rompem com os conceitos desenvolvidos nos Discursos. Roma, desde o seu início, já é percebida como discórdia, ao passo que Florença

\footnotetext{
${ }^{2}$ A questão dos humores é, tanto na obra de Maquiavel quanto na tradição política, um tema bastante complexo. Existem basicamente dois eixos interpretativos para se compreender os humores (umorı) na obra de Maquiavel: um que os analisa em termos de motivação de classe, mas que vai além de uma compreensão estática da oposição entre oprimidos e opressores; outro que os interpreta a partir a influência da teoria médica e fisiológica antiga sobre o pensamento do florentino. A adoção de termos médicos em reflexões institucionais não é algo raro no pensamento político, (Gaille Nikodimov, 2004: 33). "As duas interpretações não são necessariamente incompatíveis: [uma] privilegia as supostas origens cosmológicas dos apetites que separam segmentos da sociedade, ao passo que [a outra] privilegia os efeitos reais desses apetites, a saber, desigualdades de riqueza e de poder político" (McCormick, 2013: 255).
} 
apareceria unida até 1215 . Todavia, este ponto pode ser esclarecido pelo fato de que até esta data esta cidade não pôde desenvolver conflitos por seus habitantes estarem voltados para sua sobrevivência e independência, não havendo espaço para dissenções naturais. E, quando a disputa surge, ela nasce privada, oriunda de conflitos facciosos (Gaille Nikodimov, 2004: 19). Em outras palavras, em Florença houveram embates travados entre facções por objetivos privados, sem que destes conflitos pudessem originar boas instituições. Se o antagonismo que se coloca como motor da história é aquele no qual se opõem grandes e povo, a luta privada entre facções não leva a bons resultados.

Importante lembrar que a diferença entre a desunião entre os humores em Roma e em Florença consiste na questão dos efeitos, mais especificamente, à questão do equilíbrio. Em Roma, as desordens e tumultos promovidos pela desunião entre os humores geraram instituições equilibradas, ao passo que em Florença, levaram a profundos desequilíbrios. Para explicar melhor esta questão do equilíbrio, Gaille Nikodimov (2004) mostra a influência da teoria médica no pensamento maquiaveliano, na relação entre os humores e o equilíbrio do corpo social ${ }^{3}$. Maquiavel toma em empréstimo a noção de humor da teoria médica de seu tempo que é herdeira da tradição médica antiga galênico-hipocrática.

Assim, interpretar a concepção maquiaveliana de humor prescinde de uma menção ao corpus hipocrático, a Alcméon de Crotone, médico próximo dos pitagóricos (500 a.C) (Gaille Nikodimov, 2004: 34). Para Alcméon de Crotone tudo se constitui por pares de opostos. Em sua construção teórica há uma espécie de analogia entre o corpo humano e o corpo político, definindo a saúde como o equilíbrio entre as quatro qualidades fundamentais, o calor, o frio, o seco e o úmido, que são classificadas em pares de contrários (como na tradição pitagórica). O equilíbrio entre elas é a saúde, sendo designado pelo termo isonomia, e o desequilíbrio é a doença, designada por monarquia. O corpo fica doente quando uma potência domina outra. A correspondência entre o corpo humano e o corpo político evidencia que a isonomia deve ser tratada como uma determinação negativa, na medida em que as relações no interior de um par (calor/frio ou úmido/seco) não se equilibram quantitativamente de modo a se anularem, mas quando nenhuma qualidade domina outra e a oposição é perene. Esta é "a primeira pedra do edifício humoral". A segunda é o corpus hipocrático.

O corpus hipocrático, embora não tenha sido escrito de uma só vez e por uma única mão (tendo, inclusive, teses diversas), herda a concepção alcmeoniana. Nesta construção existiriam quatro humores fundamentais: o sangue, a fleuma, a bile amarela e a bile negra. Saúde e doença são explicadas a partir da mistura harmoniosa

\footnotetext{
${ }^{3}$ Vale ressaltar que o emprego de termos médicos no pensamento político é algo recorrente na história do pensamento desde os pré-socráticos. Todavia, o pensamento humoral não é unívoco na história do pensamento humano, nem é transmitido de forma sistemática desde que foi formulado na antiguidade. Embora o objetivo deste estudo, ao recorrer à teoria dos humores de Maquiavel, seja analisar a forma como as castas sociais se enfrentam e seus efeitos institucionais, esta reflexão pode ajudar a elucidar o caráter ambíguo com que Maquiavel trata da questão do conflito em seus escritos, bem como a necessidade de haver equilíbrio no corpo social, apesar de os enfrentamentos serem essenciais para uma vida republicana saudável.
} 
ou desarmoniosa entre os humores. Assim como em Alcméon, metáforas políticas são utilizadas significando doença. Esta tradição também considera a relação do corpo com o entorno, com o meio natural, com o que penetra do exterior (ar, bebida, alimento) e com o clima. Há saúde quando os quatro humores estão em justa proporção entre si e doença quando um dos humores, em pequena ou larga quantidade, se isola no corpo ao invés de permanecer em harmonia com os demais (Gaille Nikodimov, 2004: 35).

Na teoria galena, à teoria dos humores se acrescentam elementos aristotélicos, estóicos e platônicos, tais como a tripartição da alma, sua ligação com a mente, com o coração e com o fígado. Nela, parte-se da premissa de que a fisiologia repousa na existência de quatro elementos primeiros (fogo, ar, terra e água), cada um caracterizado por duas das quatro qualidades primeiras (calor, frio, seco e úmido): o sangue seria quente e úmido, a fleuma fria e úmida, a bile negra seca e fria e a bile amarela quente e seca. Os humores teriam relação direta com as estações (doenças relativas a excesso de fleuma surgiriam no inverno por exemplo) e com o período da vida (há na infância, maior incidência de doenças relacionadas ao excesso de sangue, na juventude, doenças ligadas ao excesso de bile amarela e na velhice, doenças relativas a fleuma). Para se compreender a doença deve-se compreender o modo como os quatro humores se relacionam no corpo, como se equilibram ao conceder uma certa predominância a um ou outro. A saúde é analisada em termos de igualdade e simetria, e a doença se relaciona com o desequilíbrio de um ou dos vários humores. Neste sentido, doença pode ser excesso ou ausência de um ou outro humor (Gaille Nikodimov, 2004).

Ao assumir só uma dualidade de humores opostos (grandes e plebe), a definição de Maquiavel se assemelha mais à dos pares opostos de Alcméon de Crotone. Todavia, esta aproximação não é total, uma vez que o esquema binário maquiaveliano, por exemplo, não corresponde à ideia alcmeoniana de uma infinidade de pares de opostos. Vale dizer, também, que o humor dos grandes é, na obra de Maquiavel, mais danoso que o humor popular para a cidade, ao passo que no esquema médico não há um humor que seja considerado como mais negativo ou positivo que os demais (Gaille Nikodimov, 2004: 36).

Por meio de uma analogia com os humores médicos pode-se observar na obra de Maquiavel: 1) a correlação entre saúde e liberdade, bem como o fato de que tanto as leis favoráveis à liberdade/saúde da cidade - Discursos, Livro I, capítulo 4 - quanto todos os males/doenças - História, Livro III, capítulo 1 - nascem da desunião entre os humores, isto é, os humores são tanto a causa da saúde (liberdade) quando da doença (corrupção e rompimento do corpo social); 2) o fato de que os humores do corpo social assim como os do corpo humano são potencialmente nocivos e desequilibrados (irrefreados; desmesurados) se considerados de forma isolada. Se na teoria médica galênico-hipocrática a saúde era compreendida como o equilíbrio entre os humores que, mesmo sendo contrários entre si, poderiam levar à harmonia sem que um anulasse o outro, a saúde do corpo social deve ser pensada de forma análoga. Maquiavel demonstra, no capítulo 4 do Livro I dos Discursos, que foi da oposição humoral tumultuária que surgiram as instituições favoráveis à liberdade em Roma que propiciaram o equilíbrio republicano e saúde ao corpo social desta cidade. Por outro 
lado, assim como a saúde do corpo humano advém da relação equilibrada entre os humores, as doenças e males também, ou seja, a relação entre humores opostos é a causa tanto da saúde quanto da doença.

É justamente a partir deste horizonte, segundo o qual a causa tanto da saúde quanto da doença, que Maquiavel afirma, no capítulo 1 do Livro III da História, algo que pode parecer contraditório com suas análises dos Discursos. que todos os males das cidades se originam da desunião entre os humores. Neste sentido, é possível inferir que para Maquiavel, tanto os males (desequilíbrio/assimetria) quanto as bênçãos (equilíbrio) do corpo político advêm da desunião conflitiva entre os humores. O que leva a um ou outro são os efeitos desta. Além disso, assim como os humores do corpo humano são, se tomados de forma isolada, desequilibrados, também o são os humores antagônicos do corpo social. Considerando a corrupção natural na qual incorrem as formas de governo "puras" devido ao fato de excluírem o humor contrário - o governo dos optimates e o governo popular -, o processo de degeneração é rápido pois não há modos de refrear o desejo de um ou outro humor, o que só é possível numa forma de governo mista, a republicana. E o mesmo ocorre no corpo humano. Conforme se exemplificou acerca de teoria médica antiga, determinadas doenças se desenvolvem justamente quando um humor passa a preponderar em detrimento dos outros.

Como o humor da plebe se formula a partir de um desejo de não ser oprimido e se marca, a princípio, por uma negatividade, poder-se-ia inferir que o humor popular seria esvaziado de qualquer conteúdo político. Noutros termos, se o humor da plebe visa a não ser dominado, surge a hipótese de que esse humor não visa a alcançar o poder, contentando-se com a simples segurança de uma liberdade privada, destituída de conteúdo político. Todavia, nem a teoria médica que influencia o pensamento de Maquiavel nem a obra do florentino dão margens para tal inferência. Afirmar que o humor da plebe é vazio de sentido coloca em xeque as convicções republicanas de Maquiavel, pois, se o povo é essencialmente passivo e ingênuo, ele não passaria de um instrumento do príncipe ou das elites. No entanto, n' O príncipe (capítulo V) há evidências de que a plebe não é puramente passiva nem apolítica. Ao tratar do problema da conquista, Maquiavel ressalta que "[...] as repúblicas são mais difíceis de conquistar, porque o apelo ao nome da antiga liberdade é um inimigo difícil de ser vencido" (Bignotto, 1991: 114). Se dominar cidades habituadas ao ethos político da liberdade é mais difícil, isso significa que há uma superioridade de regimes livres frente aos demais, o que deixa transparecer a preferência do florentino em relação aos regimes livres, pois eles são mais fortes devido à participação e irreverência do povo frente à dominação. Além de esse trecho conter um elogio implícito à liberdade, ele evidencia que tal ethos não pode ser entendido como simples negatividade. Se, conforme elucidado no capítulo anterior, os regimes fundados no elemento popular tendem a ser mais fortes e mais sólidos, uma vez que o povo é "sábio" e "ponderado" em seus juízos e em seu agir, sua forma de desejar não poderia ser "vazia" ou uma absolutamente negativa.

Não obstante, uma constituição livre é capaz de mobilizar ativamente a energia dos cidadãos contra inimigos externos numa defesa feroz da liberdade. Quando Maquiavel expõe a possibilidade de haver rebeliões em territórios livres que foram conquistados por um príncipe, ele descreve o povo segundo um princípio de ação. 
Uma rebelião, nesse caso protagonizada pelo humor popular, é uma resistência ativa, uma forma positiva de engajamento (Adverse, 2007: 37). Segundo Bignotto (1991: 115), quando Maquiavel elogia a ferocidade do povo habituado ao ethos da liberdade, "[...] ele nos força a ver no povo um ator político fundamental", não como simplesmente passivo. Também no capítulo 2 do Livro II dos Discursos, Maquiavel fala da obstinação dos romanos na defesa de sua liberdade e também na liberdade como a chave para o expansionismo romano. Todo povo que é habituado a viver em liberdade é feroz na luta contra seus inimigos, defendendo sua liberdade positivamente 4 . Também, nos capítulos 3 e 4 do Livro I, Maquiavel fala da plebe romana, que, promovendo tumultos e desordens, impôs à nobreza a criação e, posteriormente, a restauração dos tribunos, bem como a instauração de meios institucionais para a manutenção e a guarda popular da liberdade. Por sua vez, McCormick (2013: 259) afirma que o povo romano, assim como qualquer povo habituado com um ethos liberdade, "[...] é capaz de uma vívida e ativa defesa de sua liberdade, mesmo que suas motivações sejam fundamentalmente passivas ou negativas: ele quer apenas não ser dominado" (grifou-se). Mesmo que haja uma disposição passiva/negativa relacionada ao humor da plebe, o fato de o povo ter tido de conquistar seu lugar de eminência na república de Roma de forma ativa evidencia o potencial reativo/ativo do elemento popular.

Portanto, tendo em vista que todos os humores corpóreos tinham uma função específica que poderia levar o corpo humano a um estado de saúde (não sendo nenhum deles "vazio"), da mesma forma devem ser interpretados os humores políticos. O humor da plebe não é, nem deve ser interpretado, como um desejo despossuído de vontade de potência, isto é, vontade de alcançar o poder instituído. Isso porque (pressupondo a necessidade de se manter diferenciado o modo de desejar) o povo deseja alcançar o poder, tanto que lutou ativamente em Roma para alcançar espaços ativos no poder político instituído da cidade. Maquiavel inclusive expressa sua admiração pelo desejo dos plebeus de alcançar cargos e privilégios a fim de que pudessem influenciar as decisões da cidade, indo além de meramente evitar, de forma passiva, a dominação.

Vale ressaltar que uma "república doente" seria como uma comunidade política corrompida. E uma questão de grande relevância é: seria possível a uma república corrompida retomar o rumo da grandeza? Essa é justamente uma das perguntas que podem ser respondidas pela análise de $O$ príncipe. Quando a corrupção ${ }^{5}$ se agrava de

\footnotetext{
${ }^{4}$ Vale ressaltar que essa passagem não tem o objetivo de ressaltar o caráter ativo do povo, mas de elogiar a grandiosidade das conquistas romanas, que envolveram inúmeros territórios habitados por indivíduos habituados com a liberdade. Todavia, quando o florentino afirma que tais povos tendem a defender de modo feroz, engajado e, por conseguinte, ativo sua forma de vida livre, ele demonstra, ainda que implicitamente, o elemento "positivo" do desejo popular. ${ }^{5} \mathrm{O}$ tema da corrupção não é propriamente o objeto deste artigo. Todavia, vale esclarecer que o significado de corrupção na obra maquiaveliana é mais amplo que o significado do "senso comum", embora não se contraponha a ele. Um regime pode se corromper na medida em que suas leis, instituições e ordenações deixam de ser capazes de dar uma vazão institucional aos novos conflitos ou quando há um desencontro entre leis e ordenações, fazendo com que nenhuma lei (por não haver respaldo nas ordenações) possa conter os excessos dos grupos sociais.
} 
forma extrema numa república e o retorno à política saudável (uma reordenação ou uma refundação) é quase impossível, uma solução é a instauração de um regime organizado em um único governante. Só esse governante "único", desde que detentor de uma virtù excepcional, poderia fazer com que a normalidade política retornasse e a ruína certa fosse evitada: "[...] retomando a teoria polibiana das mudanças dos regimes políticos, [...] 'o principado representa o remédio que, auxiliado por extraordinária virtù, os legisladores que vêem longe procuram opor à corrupção das repúblicas'" (Martins, 2007: 31-32).

Certamente, a passagem das repúblicas corrompidas para um regime régio é problemática. Maquiavel, no capítulo 18 do Livro I dos Discursos, expõe a dificuldade que um povo encontra de, tendo se corrompido, retornar à liberdade: "De tudo o que dissemos acima provém a dificuldade, ou a impossibilidade, de nas cidades corrompidas manter ou criar uma república. Mas, em se precisando criar ou manter uma, seria necessário, antes, reduzi-la ao estado régio do que ao estado popular [...]" (Maquiavel, 2007: 76). Esse "remédio" principesco é apresentado como solução por Maquiavel nos Discursos (capítulo 18) e n' O príncipe (principado civil), "[...] de tal modo que, de quem olha dos Discursos, a boa solução ou o remédio adequado não está nos seus capítulos seguintes (XIX, XX etc.), mas no principado civil, tal qual é apresentado na primeira obra mencionada" (Martins, 2007: 31-32). Assim, os principados, quando não se constituem no contexto primitivo de fundação de povos nativos, podem emergir numa república tomada pela corrupção extrema.

Todavia, um principado não poderia ser considerado como um regime "saudável". Isso porque um regime bem ordenado deve proporcionar é um corpo institucional que: reconheça que uma comunidade política é ontologicamente dividida, e que os atores políticos não devem tentar acabar com as divisões; saiba que os segmentos das divisões presentes na polis são antagônicos, e que esse antagonismo deve ser resolvido dentro das próprias instituições, pela via ordinária; ao viabilizar vias ordinárias para a resolução dos conflitos, dê espaço participativo a todos os segmentos da comunidade política, sob pena de os grupos marginalizados recorrerem às vias extraordinárias para se inserirem (o que pode colocar em risco toda uma construção política). Nesse sentido, o bom regime não é aquele que se define por uma harmonia absoluta ou uma saúde inabalável, a qual simplesmente não pode ser alcançada devido ao fato de a vida política ser imanente conflituosa, mas aquele que, reconhecendo todas essas marcas da imanência, é capaz de ocasionar um horizonte que inscreve a ordem na desordem e a desordem na ordem, sempre se atualizando a partir dos conflitos. Ou seja, um principado, mesmo que se instaure como uma solução pontual para problemas determinados, não pode ser considera uma solução ou um "remédio" definitivo. 


\section{O GOVERNO DAS LEIS E A QUESTÃO DA CORRUPÇÃO ${ }^{6}$}

Maquiavel inova e se contrapõe à opinião de seus contemporâneos ao colocar o exemplo da constituição republicana de Roma como modelo paradigmático de grandeza (destituindo o exemplo da constituição de Esparta ou da República Veneziana deste lugar). Assim, ao invés de glorificar apenas um legislador sábio que, de uma vez por todas, confere à cidade desde a sua fundação uma ordenação estável e duradoura, ele destaca a república romana, que aperfeiçoou suas leis e ordenações ao longo da história por meio da ação popular seguindo um curso efervescente de eventos conflituosos. Neste sentido, a instituição da lei, mais do que um caminho direto (diritto cammino) mediado por uma autoridade política "legítima" e "competente", é produto da história e está diretamente imbricada com os conflitos que são inerentes a toda comunidade política. Pode-se dizer que os conflitos têm uma função imprescindível na formulação e reformulação da lei e das ordenações de uma cidade. Mas, ao se considerar a circularidade da história institucional (que envolve um eterno retorno das leis, ordenações e formas de governo), é cogente compreender a relação entre a lei e o conflito e o processo de contenção da corrupção (Ames, 2011: 22).

Assim como à liberdade e aos conflitos, ao tema da corrupção é atribuída grande atenção na obra de Maquiavel. A questão da ordenação republicana, por exemplo, é tão importante exatamente porque apenas cidades ordenadas como repúblicas tendem a ter uma vida mais longa que as demais, uma vez que seu progresso corruptivo é mais lento. Além disso, um regime tirânico pode se colocar como uma saída numa república justamente quando esta se encontra profundamente corrompida. Logo, assim como pensar e problematizar as formas institucionais aptas a manter a liberdade e o conflito são de suma importância para o florentino, o mesmo se dá com relação à corrupção. Mesmo porque é justamente com uma boa ordenação e com boas leis que a corrupção pode ser retardada e a vida do corpo político prolongada (Gaille Nikodimov, 2004).

Antes de tratar diretamente da questão da corrupção, parece necessário retomar alguns temas já trabalhados - tais como a oposição irredutível entre os humores dos grandi e do povo e o fato de as leis e ordenações advirem desta oposição -, na medida em que eles se articulam e são imprescindíveis para a compreensão tanto do processo de corrupção do uma cidade quanto das formas de conter tais processos. Ao constatar que os desejos em permanente conflito não podem ser saciados simultaneamente, Maquiavel conclui que a liberdade e a vida política (polis; vivere politico) emergem desta desunião. No modelo do conflito cívico como motor da vida política de uma comunidade política há o desejo irrefreado dos grandes em dominar de forma absoluta e o desejo irrefreado do povo em não ser dominado. Se o humor dos grandi pode, por um lado, oprimir em excesso e fazer com que o povo se volte contra os grandes, o

\footnotetext{
${ }^{6}$ Devido ao escopo deste artigo, será atribuída maior atenção a uma bibliografia que vem se consolidando a partir da influência lefortiana na interpretação do republicanismo maquiaveliano (Ames, Bignotto, Adverse). Com isso, não se ignora a proeminência das interpretações canônicas da denominada Cambridge School, mas foi feita a opção de trabalhar com os intérpretes referidos.
} 
humor da plebe pode, por outro, apoiar um tirano que prometa subjugar os opressores, o que, em ambos os casos, acabará com a liberdade e poderá levar ao fim da vida política (que pressupõe liberdade).

Igualmente, além de haver meios institucionais para regular e refrear os desejos desmesurados do povo e dos grandes, deve haver leis e ordenações capazes de manter diferenciada a forma como os humores dão vasão aos seus respectivos desejos (Ames, 2011: 23). Tomando como exemplo Florença, quando a plebe passa a adotar a mesma práxis dos grandi na busca por seus interesses (o mesmo modo de desejar) de uma nobreza que estava corrompida, defendendo o emprego de fraudes e do extraordinário para alcançar as riquezas e as glórias, é o exato momento em que a cidade passa a alternar entre a licença e a tirania. Com isso, torna-se impossível nascerem destes conflitos instituições e leis capazes de equilibrar e desafogar por vias ordinárias as insatisfações mútuas dos humores, razão pela qual dos conflitos florentinos nasciam apenas novas divisões e mais insatisfação.

Sendo o conflito decorrente da desunião entre os humores constitutivo da vida política, ele é condição de possibilidade para a existência da polis. Todavia, só é possível que a vida política exista se o conflito encontrar estruturas institucionais para Ihe dar vazão. Caso não hajam estruturas institucionais nas quais os conflitos encontrem uma "resolução ordinária", há uma grande tendência de que o humor excluído ou marginalizado da participação institucional busque formas de se saciar pelas vias extraordinárias. O risco disso é a possibilidade de que o humor que opta pelo extraordinário anule o outro, levando a um desequilíbrio intransponível que, por sua vez, gerará uma desigualdade política não cambiante e naturalizada, levando a novas divisões e ao enfraquecimento da cidade. Por esta razão, os conflitos cívicos devem, numa comunidade política saudável, se inscrever no aparato institucional e se traduzir em leis e ordenações.

Todavia, a relação entre as leis e o conflito não deve levar à falsa conclusão de que as instituições seriam um desdobramento natural e espontâneo dos enfrentamentos políticos. Primeiramente porque os tumultos e desordens apenas são férteis se forem capazes de fazer os homens agirem por necessidade. Mesmo porque é sempre possível que os conflitos extraordinários se desdobrem em guerras civis, levando o Estado à ruína ao invés de propiciar leis e instituições saudáveis (isto é, livres) caso eles não tenham, de antemão, uma expressão institucional. Quanto à necessidade de os homens agirem "por necessidade", pode-se recorrer à explicação de Maquiavel sobre a virtù do fundador na escolha do local de fundação da cidade. "[...] como os homens agem por necessidade ou por escolha, e como se vê que é maior a virtù onde haja menos escolhas, é de pensar que, para a edificação das cidades, talvez fosse melhor escolher lugares estéreis [...]", pois nestes ambientes os homens seriam obrigados a se esforçar para sua sobrevivência (oikos), sobrando menos tempo e razões para discórdias devido à pobreza do local (Maquiavel, 2007: 10). Todavia, apenas o poder (polis) é capaz de dar segurança aos homens, sendo necessário fugir de lugares estéreis. E Maquiavel vai além: se a virtù se manifesta mais quando se age por necessidade e o fundador deve buscar um lugar fértil, capaz de viabilizar ócio,

[...] quando ao ócio possibilitado pelo lugar, devem-se criar ordenações 
para que as leis os obriguem a tais necessidades, caso o lugar não o faça, e imitar aqueles que foram sábios porque, morando em terras amenas e férteis, aptas a produzir homens ociosos e inábeis para toda e qualquer ação virtuosa, para obviar aos danos porventura causados pela amenidade da terra por meio do ócio, impuseram a necessidade de exercícios aos que tivessem de ser soldados; de tal modo que, com tal ordem, eles se tornaram melhores soldados do que os das terras naturalmente ásperas e estéreis. Entre estes conta-se o reino dos egípcios, que, apesar de viverem em terra ameníssima, foi tal a força dessa necessidade ordenada pelas leis, que geraram homens excelentes (Maquiavel, 2007: 10-11).

Vale ressaltar que a multidão não se dobra a uma lei de forma espontânea, apenas se for forçada pela necessidade ou se a necessidade for mostrada a ela. E é justamente o conflito e o medo das consequências do extraordinário que impõem a necessidade da lei, que não só refreia a "[...] força constritiva própria à necessidade (porque deixa patentes os interesses contraditórios e inconciliáveis dos grupos, bem como a urgência de dar uma solução satisfatória a eles), mas impõe uma decisão na discórdia (quer dizer, sem que esta seja neutralizada)". A lei deve, então, manter os conflitos e as instituições saudáveis, de modo que os enfrentamentos não degenerem a polise a vida política. A lei deve viabilizar um espaço conflitivo no qual a desunião irá se manter diferenciada sem lutas privadas entre facções. Além disso, as leis devem criar um terreno político virtuoso no qual os enfrentamentos não irão ter por objeto a mera riqueza, mas a honra, a glória e a participação efetiva na polis. "Em outras palavras, que a luta política não assuma uma dimensão personalista nem tome um caráter privado" (Ames, 2011: 26-27).

Logo, a função das leis é marcada por uma circularidade: ao mesmo tempo em que nascem dos conflitos, os mantém sob controle e inseridos nas instituições, de modo a inibir formas extraordinárias de um humor sobrepujar o outro. É por esta razão que, como já colocado, os tumultos não são condenáveis ou elogiáveis em si mesmos, mas analisado a partir dos seus efeitos. O exemplo da constituição republicana de Roma evidencia que a virtude nasce da boa educação; a boa educação de boas leis; boas leis dos conflitos. Assim, mesmo havendo uma imbricação potencialmente sadia entre conflitos, leis e virtude, os conflitos devem se manter férteis, dotados de uma virtù que faz com que eles se reproduzam por necessidade, jamais por ambição.

É possível dizer que a plebe romana agiu por necessidade quando promoveu os tumultos em Roma ou quando abandonou a cidade, deixando-a sem defesa, situação a partir da qual surgiu o tribunato. Porém, quando o povo começa a combater por ambição, empregando meios privados em interesses pessoais ou familiares, o resultado foi a destruição da república, o que vale também para os conflitos ocorridos em Florença. Uma vez que os revoltosos eram movidos pelo desejo de riquezas, objetivando aniquilar politicamente o humor dos grandi, empregando as mesmas práticas fraudulentas que eles, os conflitos tiveram um resultado que simplesmente refletiu o caráter desmedido do desejo, gerando, com isso, mais desequilíbrio, sem que disso surgisse uma lei capaz de equilibrar o corpo social e de traduzir os conflitos numa ordenação e em leis saudáveis. 
Também no capítulo 58 do Livro I dos Discursos Maquiavel enfatiza a importância das leis. Segundo o florentino, são as leis que conservam os bons costumes de um povo e asseguram a virtude, na medida em que conservam o povo estável, prudente, grato e, até mesmo, sábio. Para ele, ao contrário da tradição, fundar o governo sobre o povo é a melhor fundação, uma vez que foi somente numa organização popular que Roma aumentou seus domínios e alcançou a glória. Mesmo que o desejo de povo seja, em princípio, irrefreado, se houverem boas leis, ele é o agente político mais qualificado para abrir o político. Em outras palavras, "[...] vivendo sob o regime de boas leis, o povo não precisa mais da tutela do príncipe nem dos nobres para zelar pelo bem comum". E Maquiavel vai além: somente o povo pode cuidar da conservação do bem comum, uma vez que, sendo o bem algo comum, ele é de todos e, tendo o povo menor interesse em usurpá-lo, a ele deve caber sua guarda. "E nessa afinidade entre povo e bem comum fica explicitada a razão dessa devoção: o bem comum se identifica com o próprio governo das leis, vale dizer, com a própria liberdade, que tem de ser garantida pelos próprios cidadãos" (Adverse, 2013: 107). O povo, na medida em que deseja a liberdade, deve se colocar como o guardião da supremacia da lei.

Recorrendo às metáforas médicas, o papel das boas leis deve ser o de viabilizar uma "mistura institucional saudável" e equilibrada dos humores, de ocasionar à comunidade política um ethos da liberdade. As leis (legge) e as ordenações (ordine), para Gaille Nikodimov, são termos que não denotam, exatamente, o significa moderno, embora a ele não se contraponham7. As leis, no pensamento de Maquiavel, possuem uma série de significados, tendo em vista que o florentino emprega tal termo de forma relativamente livre. "Lei" pode significar costumes, estatutos, plebiscitos, decretos e todas as regras semelhantes a isso, assim como garantias e direitos frente ao humor opressor dos grandi. Mas, mais importante que as leis em si mesmas são as condições ou ordenações (ordine) que elas devem criar numa mistura saudável: a mistura republicana e propícia para a liberdade.

Todavia, a expressão institucional dos conflitos cívicos entre os grandes e o povo não é suficiente para a manutenção da liberdade. A organização republicana, ao misturar as três formas de governo e abarcar os dois humores no aparato institucional, se traduz numa mistura essencialmente precária, que é subvertida sem cessar pela dinâmica irrefreada dos desejos. Por essa razão que Maquiavel insiste, nos Discursos, na necessidade de completar constantemente a ordem de uma república popular com

\footnotetext{
${ }^{7} \mathrm{O}$ termo leges, a partir de 451-450 a.C., passa a designar um certo número de usos do direito costumeiro, sendo este marcado por um conjunto de leis escritas promulgadas pela assembleia do povo. Antes disso, o direito se constituía apenas por um conjunto de regras não escritas válidas para todos os cidadãos romanos. Com a leges, o direito costumeiro é enriquecido por fórmulas escritas. Maquiavel, em sua obra, não emprega este termo diferenciando-os de outros segundo um olhar técnico sobre o significado. A diferenciação entre as leis escritas, as costumeiras e aquelas que dizem respeito ao campo da moralidade não parece ser uma preocupação para Maquiavel, uma vez que ele utiliza termos como medida, lei e ordem para designar o mesmo instituto, que é a censura romana (o que pode ser constatado no capítulo 49 do Livro I dos Discursos) (Gaille Nikodimov, 2004: 38).
} 
novas leis. Um meio possível para suprir esta necessidade é a adaptação do corpo de leis à mutação dos costumes no transcorrer da história.

A necessidade de complementar e aperfeiçoar o quadro ordenador da república de forma a mantê-la saudável não se trata de uma mera regulação dos desejos, mas de conduzi-los de modo que eles se expressem no quadro jurídico oferecido pela ordem institucional. Este dispositivo de complementariedade deverá agir tanto refreando os humores quanto satisfazendo-os parcialmente, tendo, sobretudo, a função de limitação da ambição e da insolência dos grandes, bem como atender ao desejo popular no sentido de desafogar como uma modalidade de lei ou de instituição (Gaille Nikodimov, 2004: 48).

Neste sentido, os capítulos 24, 28, 29, 30 e 31 do Livro I dos Discursos salientam a importância de, em um regime republicano (no qual há o governo das leis), se estabelecer um esquema de recompensas e punições aos cidadãos, de modo a beneficiar as ações que tenham como telos o bem comum, bem como de corrigir os atos que tenham como objetivo lesar o bom governo das leis em vista de um interesse privado (Gaille Nikodimov, 2004: 48). Assim, a confrontação dos humores obriga a rever permanentemente a ordem institucional da cidade: Maquiavel renuncia definitivamente à ideia de que existam leis capazes de regular de uma vez para sempre o conflito dos desejos.

\section{CONSIDERAÇÕES FINAIS}

O corpo político ordenado com boas leis é saudável e, assim como um corpo humano saudável, poderá ter uma vida mais longa que os doentes. E, assim como o corpo humano, por mais saudável que seja, encontra seu fim natural na morte com o natural desequilíbrio dos humores (que leva, por exemplo, a uma morte natural decorrente da velhice), o mesmo ocorre com uma polis. Como o próprio Maquiavel explicita, todo império há de encontrar o seu fim. O papel das leis e ordenações é retardar este fim inevitável que, se não decorrer de uma invasão ou uma conquista externa, se deverá à corrupção natural da cidade, decorrente dos desequilíbrios entre os humores.

Portanto, mais do que criar um regime ideal, transcendente ou com leis absolutas, uma cidade governada por leis deve ser capaz de, com a confrontação entre os humores, rever de forma permanente a sua ordem institucional de modo que as leis continuem a governar, criando um ciclo virtuoso: os conflitos geram boas leis; as boas leis ocasionam boas ordenações; as boas ordenações propiciam cidadãos virtuosos (tanto no povo quanto entre os grandes); a virtude cívica faz com que os atores políticas sejam capazes de traduzir os conflitos em boas leis, atualizando assim as ordenações. Vale, por fim, apenas pontuar que este ciclo virtuoso não significa que uma cidade ou um império será eterno. Assim como o corpo humano, todo e qualquer corpo político encontrarão, ao final, a morte, podendo esta apenas ser retardada por leis ou "remédios políticos" saudáveis. 


\section{BIBLIOGRAFIA}

Adverse, H. (2007). Maquiavel, A República e o Desejo de Liberdade. Trans/Form/Ação, v. 30, p.33-52.

Ames, J. L. (2014). História e Ação Política em Maquiavel. Mediações, vol. 9, n. 1, p.101-118.

Ames, J. L. (2011). Lei e violência ou a legitimação política em Maquiavel. Trans/Form/Ação, v.34, n.1, p.21-42.

Ames, J. L. (2009). Liberdade e conflito - O confronto dos desejos como fundamento da ideia de liberdade em Maquiavel. Kriterion, Belo Horizonte, n. 119, p.179-196.

Ames, J. L. (2014). Transformações do significado de conflito na História de Florença de Maquiavel. Kriterion, Belo Horizonte, n. 129, p.265-286.

Gaille-Nikodimov, M. (2004). Conflit civil et liberté. La politique machievélienne entre histoire et médecine. Paris: Honoré Champion.

McCormick, J. (2013). Democracia maquiaveliana: controlando as elites com um populismo feroz. Tradução de André Villalobos. Revista Brasileira de Ciência Política, n 12, Brasília, p.253-298.

McCormick, J. (2011). Machiavellian democracy. Nova lorque: Cambridge University Press.

Maquiavel, N. (2007a). Discursos sobre a primeira década de Tito Livio. Glossário e revisão técnica de Patrícia Fontura Aranovich. Tradução MF. São Paulo: Martins Fontes.

Maquiavel, N. (2007b). História de Florença. Glossário e revisão técnica de Patrícia Fontura Aranovich. Trad. MF. São Paulo: Martins Fontes.

Maquiavel, N. (2001). O príncipe. Tradução de Maria Júlia Goldwasser. 2 ed. São Paulo: Martins Fontes.

Martins, J. A. (2007). Os fundamentos da república e sua corrupção nos Discursos de Maquiavel. Tese de doutorado apresentada ao Programa de Pós-graduação em 
Filosofia da Faculdade de Filosofia, Letras e Ciências Humanas da Universidade de São Paulo.

Morais, R. M. O. (2014). O Conflito e a História na teoria republicana: contraponto entre Guicciardini e Maquiavel. Temporalidades, v.6, n.1.

Valverde, A. (1999). A liberdade cívica no Livro I dos Discorsi de Maquiavel. Hypnoe, ano 4, n. 5, p.337-354. 